DOI https://doi.org/10.30525/978-9934-26-111-4-39

\title{
РЕКРЕАЦІЙНИЙ ПОТЕНЦІАЛ БАЛЬНЕОЛОГІЧНИХ РЕСУРСІВ ТЕРНОПІЛЬСЬКОЇ ОБЛАСТІ
}

\author{
Питуляк М. Р. \\ кандидат географічних наук, \\ дочент кафедри географії і методики ї̈ навчання
}

Тернопільський національний педагогічний університет

імені Володимира Гнатюка

\section{Питуляк М. В.}

кандидат географічних наук,

дочент кафедри географії і методики ї̈ навчання

Тернопільський національний педагогічний університет

імені Володимира Гнатюка

\section{Стецько Н. П.}

кандидат географічних наук,

доиент кафедри геоекології і методики викладання геоекологічних

дисииплін

Тернопільський національний педагогічний університет

імені Володимира Гнатюка

м. Тернопіль, Украӥна

У Тернопільській області виявлені і досліджені різні види мінеральних вод і торфових грязей, які широко використовуються в курортному господарстві області і сприяють розвитку лікувальнооздоровчої рекреації.

Метою цієї публікації $\epsilon$ аналіз рекреаційного потенціалу бальнеологічних ресурсів Тернопільської області.

Бальнеологічні рекреаційні ресурси - це природні лікувальні речовини, які використовуються для немедикаментозного лікування i $\epsilon$ основою формування санаторно-курортного господарства. До бальнеологічних ресурсів відносять мінеральні води, лікувальні грязі (пелоїди), а також - озокерит (гірський віск).

Дослідження бальнеологічних ресурсів області має дуже важливе значення для розвитку курортного господарства як Тернопільщини так і для всієї країни. 
Бальнеологічні ресурси Тернопільської області є основою формування курортно-рекреаційних районів. Структурно і функціонально вони пов'язані з лікувально-оздоровчими місцевостями, під якими, згідно з Законом України «Про курорти» (стаття 1), розуміються природні території, що мають мінеральні та термальні води, лікувальні грязі, озокерит, ропу лиманів та озер, кліматичні та інші природні умови, сприятливі для лікування, медичної реабілітації та профілактики захворювань.

Дослідженням бальнеологічних ресурсів Тернопільської області впродовж багатьох років займалися вчені-медики, географи, природознавці. Серед них В.Апостолюк, Г.Чернюк, Л. Царик, Я. Мариняк, М. Питуляк, М. Питуляк та ін. Перші дослідження мінеральних вод i торфових грязей (Микулинецького, Гусятинського, Конопківського родовищ) було проведено В.В.Апостолюком. Він у 1964 р. захистив кандидатську дисертацію на тему «Лікувальні властивості торфових грязей Тернопільської області».

У Тернопільській області сформувалися слабомінералізовані води, а також розчини, склад яких відповідає вимогам, до мінеральних вод. На території Тернопільської області за іонно-сольовим і газовим складом виявлені такі типи мінеральних вод: мінеральні води без специфічних компонентів різного іонного складу, сульфідні води та води з високим вмістом органічних речовин

3 урахуванням наявності мінеральних вод різноманітного складу, лікувальних грязей, сприятливих кліматичних умов та ресурсів, особливостей місцевості (рельєфу, рослинності, водних ресурсів), в області, можна виділити райони з різним потенціалом для бальнео та грязелікування [4].

Найвищий рекреаційний потенціал мають бальнеологічні ресурси у Гусятинському районі. Оздоровчо-лікувальними ресурсами цього району є природні особливості: мальовничі горбисті місцевості, вкриті лісами; долина Збруча з високими скелястими берегами. Рекреаційний потенціал мають гідромінеральні ресурси, представлені двома типами мінеральних вод: типу «Нафтуся» та хлоридні натрієві, або хлориднокальцієво-натрієві високомінералізовані і розсольні води 3 мінералізацією 34,1...39,4 г/л типу «Друскінінкай». Лікувальні властивості підземних вод використовують у лікувальних закладах смт. Гусятин.

На околиці селища Гусятин у лісопарковій зоні розташований санаторій «Збруч». Він функціонує з 1986 року на базі Новозбручанського родовища мінеральних вод як бальнеологічна оздо- 
ровниця, 3 власним лікувально-оздоровчим комплексом. Основним лікувальним фактором $є$ природні мінеральні води двох типів: слабомінералізована гідрокарбонатно-кальцієво-магнієва 3 підвищеним вмістом органічних речовин вода «Новозбручанська» типу «Нафтуся» та високо-мінералізована вода «Рапа» типу «Друскінінкай».

У жовтні 2016 року на базі реабілітаційного відділення Гусятинської районної лікарні було закладено водолікарню. Новостворена бальнеологічна лікарня функціонуватиме на базі родовища мінеральних вод «Новозбручанське», яке складається 3 двох типів води: слабомінералізованої, типу «Нафтуся», 3 підвищеним вмістом органічних речовин (мінералізація води становить 0,6-0,9 г/л) і високо-мінералізованої гусятинської ропи з мінералізацією 20-30 г/л, яка за фізикохімічним складом ідентична лікувально-мінеральним водам Моршина та Прибалтійського курорту «Друскінінкай» [3].

Крім мінеральних вод, у районі $\epsilon$ значні запаси лікувальних торфових грязей (сс. Глібів, Клювинці, Коцюбинці).

У центральній частині області значний рекреаційний потенціал мають бальнеологічні ресурси Микулинецько-Теребовлянського району. Гідромінеральні ресурси району представлені сірководневими водами та хлоридно натрієвими або хлоридно-кальцієво-натрієвими високомінералізованими і розсолами 3 мінералізацією $65,0 \ldots 175,0$ г/л, в окремих місцях $з$ підвищеним вмістом брому. Наявність торфових лікувальних грязей сприяє розвитку тут грязелікування.

Санаторій «Медобори» в с. Конопківка Теребовлянського району $є$ науково-дослідною базою кафедри курортології та фізіотерапії Тернопільського медичного університету. Тут успішно лікують серцевосудинну систему, хвороби опорно-рухового апарату, кісток, м'язів, сухожиль, а також радикуліти, неврити, неврози.

Важливе значення для лікування і оздоровлення має Микулинецька водогрязелікарня, яка стала в 1967 р. обласною фізіотерапевтичною лікарнею реабілітації. Вона оснащена сучасною діагностичною i лікувальною апаратурою. До послуг хворих тут $є$ бальнеологічні відділення і лікувально-діагностичні кабінети. Обласна фізіотерапевтична лікарня реабілітації знаходиться у мальовничому старому парку площею 5 га на березі р. Серет [5, с. 425].

У південній частині області сформувався Борщівсько-Заліщицький район санаторно-курортного лікування і оздоровлення. Він займає південну частину області 3 найсприятливішими кліматичними умовами, сприятливим рельєфом та ландшафтами, а також мінеральними водами та грязями. Температурний режим характеризується 
високими літніми температурами $\left(+18,5 \ldots 19,2^{\circ} \mathrm{C}\right)$ та тривалим - $106-$ 108 днів комфортним періодом 3 температурами, вищими $3 \mathrm{a}+15^{\circ} \mathrm{C}$. Теплий, м'який клімат рекомендований як один із лікувальних факторів при початкових формах захворювання туберкульозом легенів, лікуванні хворих на гіпертонію на ранніх стадіях з початковими формами атеросклерозу, при неврастенії. Лісові масиви мають найсприятливіші умови для фітотерапії. В межах Борщівсько-Заліщицького району в багатьох місцях спостерігаються природні джерела мінеральних вод. Гідромінеральні ресурси представлені мінеральними водами різного складу: прісні і слабо мінералізовані, нафтусеподібні води 3 коливанням вмісту органічних речовин, гідрокарбонатнонатрієві; мало-і середньомінералізовані води типу «Миргородська» та високомінералізовані типу «Друскінінкай», хлоридні, гідрокарбонатно-хлоридні та сульфатні. Воду рекомендовано використовувати при лікуванні захворювань шлунково-кишкового тракту та зовнішніх процедур.

На основі бальнеологічних ресурсів у смт. Більче Золоте працює обласна лікарня фізіотерапії та реабілітації як провідний спеціалізований лікувально-профілактичний заклад Тернопільської області. За 65 років лікарняний заклад перетворився із сільської лікарні на великий оздоровчий комплекс, де одночасно можуть покращити своє здоров'я 200 осіб. Щорічно тут оздоровлюється близько 4 тисяч пацієнтів. Лікувально-оздоровча база Більче-Золотецької обласної фізіотерапевтичної лікарні реабілітації - це: радонові та радоновоперлинні ванни; вихрові радонові ванни; сірководневі ванни; хвойні ванни та багато інших процедур [2].

Лікувально-курортна рекреація розвивається в районах концентрації природних рекреаційних ресурсів: бальнеологічних, кліматичних, лісових, водних та інших. Всього в області нараховується 18 санаторнокурортних закладів та закладів відпочинку. Переважна більшість закладів відпочинку та оздоровлення мають сезонний характер роботи.

Серед санаторно-курортних закладів лідерами за кількістю осіб, що в них відпочивають, є: санаторій «Медобори» с. Конопківка Теребовлянського району - понад три тисячі оздоровлених $(19,9 \%$ від загальної кількості оздоровлених по області).

Ресурсний потенціал мінеральних вод і торфових грязей в області використовується на жаль неефективно. Лікувально-оздоровча рекреація мала б стати одним із пріоритетних напрямків розвитку рекреації та туризму в області за умов залучення інвестиційних 
ресурсів для розвитку цієї сфери, належного фінансування та розвитку інфраструктури.

\title{
Література:
}

1. Закон України «Про курорти». URL: zakon.rada.gov.ua/go/ 2026-14.

2. Більче-Золотецька обласна фізіотерапевтична лікарня URL: http://www.bzlik.te.ua/index.php/ua/

3. Гусятинська водолікарня URL: http://hata.te.ua/2018/12/04/zazdorov-iam-u-husiatyn/

4. Питуляк М.Р. Природні рекреаційні ресурси Тернопільщини, проблеми їх раціонального використання та охорони. Навч. посібник /М.Р.Питуляк. - Тернопіль, 1999. - 60 с.

5. Питуляк М.Р., Питуляк М.В. Санаторно-курортна сфера та лікувально-оздоровчий туризм. Географія Тернопільської області: монографія. В 2-х томах. Т. 2. Населення господарство. Тернопіль: Осадца Ю.В., 2020. С. 424-431

DOI https://doi.org/10.30525/978-9934-26-111-4-40

\section{ЗАЛІЗНИЧНИЙ ТРАНСПОРТ ЯК ВАЖЛИВА СКЛАДОВА ТУРИСТИЧНОЇ ІНФРАСТРУКТУРИ РІВНЕНЬКОЇ ОБЛАСТІ}

\author{
Слащук А. М. \\ кандидат географічних наук, \\ доцент кафедри економічної та сочіальної географії \\ Волинський національний університет імені Лесі Украӥнки \\ Бернадська Г. О. \\ аспірантка кафедри економічної та сочуіальної географії \\ Волинський національний університет імені Лесі Украӥнки \\ м. Луцькк, Украӥна
}

Транспортний комплекс - один 3 найважливіших складових туристичної інфраструктури кожного регіону. Він включає автомобільне, залізничне, повітряне сполучення та міський електротранспорт. 